Journal of Food Technology 8 (1): 24-29, 2010

ISSN: $1684-8462$

(C) Medwell Journals, 2010

\title{
Physicochemical and Sensory Properties of Cassava Flour Biscuits Suplemented with Cashew Apple Powder
}

\author{
M.A.K. Ogunjobi and S.O. Ogunwolu \\ Crop Processing and Utilization Division, Cocoa Research Institute of Nigeria, \\ P.M.B. 5244, Ibadan, Nigeria
}

\begin{abstract}
Cassava roots were processed into flour using standard method. Cashew apples were sliced, dried (at $65^{\circ} \mathrm{C}$ ) and ground to produce Cashew Apple Powder (CAP) and used at different levels of cassava flour substitution for biscuits formulations. The effects of cashew apple powder supplementation on physicochemical and sensory characteristics of the biscuits were evaluated. The protein, fibre, ash and vitamin $\mathrm{C}$ content were significantly affected. Weights, heights, diameter and spread ratio were similar to whole cassava flour biscuits. Sensory evaluation of the biscuits showed that supplementation of cassava flour biscuits with $\mathrm{CAP}$ up to $20 \%$ did not significantly affect the colour, texture, crispness and taste $(\mathrm{p}<0.05)$ when compared with the control sample. However, biscuit with $25 \%$ CAP was significantly different from the other samples in all parameters evaluated. The supplementation seems to be suited for cassava flour substitution and it is possible to obtain biscuits of better quality within the standards for biscuits.
\end{abstract}

Key words: Physicochemical, supplementation, sensory, cassava flour, CAP

\section{INTRODUCTION}

Increasing urbanization in African countries is changing the food habits and preferences of the population towards convenience food. Bread, biscuits and other baked products are some of the foods now relished by the populace (Oyewole et al., 1996). Biscuits are ready-to-eat, convenient and inexpensive food product, containing digestive and dietary principles of vital importance (Kulkarni, 1997). The principal ingredients are flour, fat, sugar and water; while other ingredients include milk, salt, flouring agent and aerating agent (Wade, 1988).

In the past, before the ban on importation of wheat in Nigeria, biscuits were made from $100 \%$ wheat flour. Nigeria has unfavourable climatic conditions for wheat cultivation but suitable for tropical crops such as roots, tubers and cereals. Therefore, consumption of cereal based foods like biscuits require development of an adequate substitute for wheat (Eneche, 1999). Because of the high cost of wheat flour, which is usually imported into Nigeria, flour and starch materials were sourced locally from tropical crops such as roots and tubers (cassava, yam and sweet potato) and cereals (maize, rice, sorghum and millet) to replace wheat flour. Among the roots and tubers, cassava is the best choice to replace wheat partially or completely due to its high yield and low cost of production (Almazan, 1987).
Cassava Flour (CF) is one of the major products from cassava roots traded in the world food market. The future of Nigeria as one of the leading CF exporting countries is particularly bright as its export capacity had risen from about $230 \mathrm{Mt}$ in 1988 to about 10,975 Mt in 2003 (FAO, 2004). Similarly, CF has also continued to find wider applications in food, feed and chemical industries (Balagopalan, 2002). One of the most popular uses of CF worldwide is in the manufacture of baked products (Shittu et al., 2008).

The cashew tree (Anacardium occidentale) is one of the major plantation crops grown in Nigeria. The fruit consists of mainly the nuts containing an embryo (kernel) and a false fruit commonly called cashew apple (Akinwale, 2000). According to FAO (2008), Nigeria produced $660,000 \mathrm{Mt}$ of raw nuts in 2007 and given the weight ratio of apple to nut at 8:1 (Cormier, 2008), the annual production of cashew apple in Nigeria is about 5.2 million Mt most, which is left to rot in the field under the trees. One of the main causes for this is the short post harvest life of the fruit, coupled with the nonexistent industrialization capacity and the short harvest period (February to April).

Cashew apple is a valuable source of minerals and vitamins. Indeed, cashew apple juice is reported to contain five times as much vitamin $\mathrm{C}$ as citrus juice (Akinwale, 2000) and ten times as pineapple juice (Ohler, 1988). The cashew apple juice also has medicinal

Corresponding Author: M.A.K. Ogunjobi, Crop Processing and Utilization Division, Cocoa Research Institute of Nigeria, P.M.B. 5244, Ibadan, Nigeria 
uses. For instance, its high tannin content makes it suitable remedy for sore throat and chronic dysentery in Cuba and Brazil (Morton, 1987). It is also, reported to have anti-bacterial, anti-oxidant (Melo-Cavalcante et al., 2003) and anti-mutagenic (Cavalcante et al., 2005).

The studies carried out at Cocoa Research Institute of Nigeria (CRN) revealed that the present consumption of cashew apple either in raw or processed form is about $10 \%$ of production (Oduwole et al., 2001). The practical implication of this is that about $90 \%$ of cashew apple production is being wasted annually in Nigeria. Hence, there is need to preserve it for further utilization in the development of some products, which would be acceptable to consumers.

As a result of the need to find a wider use for cashew apples, the cashew producing countries of the world have explored and developed many different products. The reported researches on the products from cashew apple included fermentation of juice into wine (Aderiye et al., 1991; Akinwale, 1999; Shuklajasha et al., 2005); preparation of jam and preserves (Ogunmoyela, 1983); conversion of apple juice into alcohol and non-alcoholic beverages, candied fruit, fresh juice, jelly, syrup and pectin (Winterhalter, 1991) and sun-dried cashew apple (Morton, 1987).

The drying of cashew apple can be an excellent alternative to increase its shelf-life. It allows conversion of perishable materials into stabilized product by lowering the water activity to appropriate levels. It also prevents microbial spoilage and quality deterioration due to undesirable biochemical reactions. In addition, drying reduces waste and post-harvest losses. The development of dried cashew apple (cashew apple powder), which maintain the relevant sensory properties as unaltered as possible, can contribute to the development of some value added products, which would be acceptable to the consumers.

Partial substitution of wheat flour with cassava flour up to $40 \%$ has been reported for biscuits by Kim and DeRuiter (1968), Morton (1988), Eggleston et al. (1993), Omoaka and Bokanga (1994), while 100\% substitution of wheat flour with cassava flour for biscuits was reported by Oyewole et al. (1996). However, the physicochemical analyses of the biscuits made from $100 \%$ cassava flour revealed that the biscuits had low protein and fat content when compared with biscuits made from $100 \%$ wheat flour. Therefore supplementation of cassava flour with Cashew Apple Powder (CAP) will increase the nutritional quality of the biscuits.

This study was aimed at processing cashew apple into powder, develop a biscuit formulation from cassava flour and cashew apple powder with good acceptability and evaluate the effect of CAP supplementation on the physicochemical and sensory characteristics of biscuits produced.

\section{MATERIALS AND METHODS}

Ripe, matured fruits (yellow variety) were harvested at the cashew plantation of Cocoa Research Institute of Nigeria (CRIN) headquarters, Ibadan, Nigeria for the preparation of the powder. Cassava roots (low cyanide clone) from 8 months old plant of a local cultivar (TMS 30555) were obtained from a farm in Ibadan for the preparation of the flour. Other materials include Simas margarine (PT Intiboga Sejahtera, Aakartaa, Indonesia), Salt and sugar (Dangote Nigeria Plc., lagos), Edlen Dough Conditioner (EDC) (Edlen International Inc., Nigeria), eggs and milk powder were purchased from a local market in Ibadan, Oyo State, Nigeria.

Preparation of Cashew Apple Powder (CAP): Ripe, matured fruits (yellow variety) were harvested and the nuts were detached from the apple manually and the apples were sorted, weighed and washed with sodium metabisulphite solution $(350 \mathrm{ppm})$ to remove any contaminants from the farm. Cashew apples were cut into small pieces of approximately, $1.0 \times 1.0 \mathrm{~cm}$ with stainless steel knife and placed in stainless trays for drying process. The samples were oven dried at $65^{\circ} \mathrm{C}$ for $12 \mathrm{~h}$, until the final moisture attained $7.0 \%$. After drying, the dried apple pieces were left to cool in desiccators and then ground in a domestic blender (Phillips brand) at low velocity for $5 \mathrm{~min}$. Afterwards, the material was sieved to obtain a powder with an average particle size of $6 \mu \mathrm{m}$. The weight of the obtained cashew apple powder was recorded and immediately sealed in polyethylene bags and stored at room temperature $\left(28^{\circ} \mathrm{C}\right)$.

Preparation of Cassava Flour (CF): Cassava flour was prepared according to the methods described by Oyewole et al. (1996).

Biscuit formulation and preparation: The biscuits were made according to the method described by Oyewole et al. (1996) with some modifications. In all cases, the products contained $10,15,20$ and $25 \mathrm{~g} / 100 \mathrm{~g}$ of cashew apple powder in relation to cassava flour content as shown in Table 1.

Margarine and sugar were mixed in a Kenwood mixer at a medium speed until a light and fluffy cream was formed. One whole egg (medium size) and milk powder were added while mixing. Then cassava flour, cashew apple powder, baking powder and salt were slowly 
Table 1: Biscuit formulations with different percentage of cashew apple powder

\begin{tabular}{lccccc}
\multicolumn{5}{c}{ powder } & \multicolumn{7}{c}{ Levels of substitutions } \\
& & $10 \%$ & $15 \%$ & $20 \%$ & $25 \%$ \\
& & & \\
& Control & CAP & CAP & CAP & CAP \\
\hline Ingredients & 100.00 & 90.00 & 85.00 & 80.00 & 75.00 \\
Cassava flour (g) & 35.00 & 35.00 & 35.00 & 35.00 & 35.00 \\
Margar (g) & 40.00 & 40.00 & 40.00 & 40.00 & 40.00 \\
Milk powder (g) & 10.00 & 10.00 & 10.00 & 10.00 & 10.00 \\
Baking powder (g) & 2.00 & 2.00 & 2.00 & 2.00 & 2.00 \\
Salt (g) & 0.50 & 0.50 & 0.50 & 0.50 & 0.50 \\
Egg (medium) & 1 & 1 & 1 & 1 & 1 \\
Cashew apple & - & 10.00 & 15.00 & 20.00 & 25.00 \\
powder (g) & & & & & \\
\hline
\end{tabular}

CAP: Cashew Apple Powder

introduced into the mixture. The dough obtained was rolled on a flat rolling board sprinkled with flour to a uniform thickness of $0.4 \mathrm{~cm}$ using wooden rolling pin and guiding sticks. Circular biscuits of $5.52 \mathrm{~cm}$ diameter were cut, placed on greased baking trays and baked in an electric oven (Gallenkamp, UK) at $150^{\circ} \mathrm{C}$ for $15 \mathrm{~min}$.

Physicochemical analyses: $\mathrm{CF}, \mathrm{CAP}$ and biscuits were analysed for moisture, ash, crude protein, crude fat, crude fibre and carbohydrate (by difference) and vitamin C content according to the methods of Kirk and Sawyer (1991). Weight, diameter and height of the biscuits were measured as described by Oyewole et al. (1996). All analyses were performed in triplicates.

Sensory analyses: Sensory evaluation was conducted using a semi-trained panel of twenty judges. Five coded samples of biscuit were presented to each of the judges and they were asked to assess the biscuits for colour, texture, crispness, taste, aroma and overall acceptability using 7-point hedonic scale ( $1=$ Dislike very much, $2=$ Dislike moderately, $3=$ Dislike slightly, $4=$ Neither like nor dislike, $5=$ Like slightly, $6=$ Like moderately, $7=$ Like very much), for the assessment. Biscuits made from 100\% cassava flour were included in the products assessed as the reference sample.

Statistical analyses: Data were subjected to analyses of variance and means were separated using Duncan's multiple range test at $\mathrm{p}<0.05$ (Steel and Torrie, 1980; Gomez and Gomez, 1985).

\section{RESULTS AND DISCUSSION}

The chemical compositions of cashew apple powder and cassava flour are shown in Table 2. There were significant differences in all the parameters considered $(p<0.05)$. The higher value for crude protein content and the presence of vitamin $\mathrm{C}$ in CAP played an important role
Table 2: Physicochemical composition of cashew apple powder and cassava \begin{tabular}{lll} 
flour & & \\
\hline Parameters & Cashew apple powder & Cassava flour
\end{tabular}

\begin{tabular}{lcc}
\hline Parameters & Cashew apple powder & Cassava flou \\
\hline Moisture (\%) & $7.05^{\mathrm{a}}$ & $7.40^{\mathrm{a}}$ \\
Crude protein (\%) & $12.75^{\mathrm{a}}$ & $1.50^{\mathrm{b}}$ \\
Crude fibre (\%) & $4.08^{\mathrm{a}}$ & $1.30^{\mathrm{b}}$ \\
Crude fat (\%) & $4.85^{\mathrm{a}}$ & $0.21^{\mathrm{b}}$ \\
Ash (\%) & $2.70^{\mathrm{a}}$ & $1.60^{\mathrm{b}}$ \\
Carbohydrate (\%) & $68.60^{\mathrm{b}}$ & $88.00^{\mathrm{a}}$ \\
pH & $4.72^{\mathrm{b}}$ & $6.30^{\mathrm{a}}$ \\
Vitamin C (mg/100g) & 52.60 & - \\
\hline
\end{tabular}

Values are means of three replicates; sample means with the same alphabets along the rows are not significantly different at $\mathrm{p}<0.05$

in chemical composition and overall quality of the biscuits made with its supplementation at various levels. All the values obtained for Cassava flour are similar and are within the range of proximate composition and specification for commercial cassava flour (Gomez et al., 1983).

Table 3 showed, the chemical compositions of the biscuit samples. There were no significant differences $(\mathrm{p}<0.05)$ in relation to moisture content in all the biscuit samples made with different percentage of CAP. The average moisture content value of the biscuits made with CAP $(7.0 \%)$ was $>2.0 \%$. Smith (1972) establishes that total moisture content for biscuits should not exceed $14 \%$ and that $5 \%$ is the best. Therefore, the moisture contents of the biscuits supplemented with CAP were within the acceptable level.

The $\mathrm{pH}$ of the biscuit samples decreased significantly $(\mathrm{p}<0.05)$ with CAP supplementation. The biscuit samples supplemented with 10 and $15 \%$ CAP were significantly different from samples supplemented with 20 and $25 \%$ $\mathrm{CAP}$ and the control sample. The $\mathrm{pH}$ values in all the biscuit samples were $>6.0$ being considered non acidic food product. Smith (1972) suggested that $\mathrm{pH}$ is an important parameter associated to biscuit flavour.

The fibre content of the biscuits significantly increased $(\mathrm{p}<0.05)$ with the level $(10,15,20$ and $25 \%)$ of incorporation of CAP, while the control sample had least value for fibre. This could be due to the initial crude fibre in the CAP. Samples supplemented with 10 and $15 \%$ CAP were significantly different from the samples supplemented with 20 and $25 \%$ CAP while the control sample was significantly different from all the CAP supplemented biscuit samples. However, these values were within the range reported for high fibre cookies (Larrea et al., 2005; Camire et al., 2007).

There were significant differences $(\mathrm{p}<0.05)$ in protein level of the supplemented biscuits proportional to the level of CAP addition. The protein content increased with increased percentage of CAP. This could be due to the protein content of the CAP since other ingredients in the formulation for all the samples were the same. Though, the highest protein content $(8.35 \%)$ was found in biscuit 
Table 3: Chemical composition of biscuit made from CF supplemented with CAP

\begin{tabular}{|c|c|c|c|c|c|c|c|}
\hline $\begin{array}{l}\text { Biscuits } \\
\text { CF:CAP }\end{array}$ & $\begin{array}{c}\text { Moisture } \\
(\%)\end{array}$ & $\begin{array}{l}\text { Fat } \\
(\%)\end{array}$ & $\begin{array}{l}\text { Protein } \\
(\%)\end{array}$ & $\begin{array}{l}\text { Ash } \\
(\%)\end{array}$ & $\begin{array}{c}\text { Fibre } \\
(\%)\end{array}$ & $\mathrm{pH}$ & $\begin{array}{l}\text { Vitamin C } \\
(\mathrm{mg} / 100 \mathrm{~g})\end{array}$ \\
\hline $100: 0$ & $6.90^{a}$ & $15.40^{\mathrm{a}}$ & $5.85^{c}$ & $1.82^{b}$ & $1.30^{\circ}$ & $6.60^{b}$ & $1.74^{\circ}$ \\
\hline $90: 10$ & $7.00^{\mathrm{a}}$ & $15.64^{\mathrm{a}}$ & $7.50^{b}$ & $2.05^{b}$ & $1.60^{b}$ & $7.20^{\mathrm{a}}$ & $19.50^{b}$ \\
\hline $85: 15$ & $6.90^{\mathrm{A}}$ & $15.78^{4}$ & $7.89^{b}$ & $2.42^{\mathrm{a}}$ & $1.80^{b}$ & $7.00^{\mathrm{a}}$ & $20.22^{b}$ \\
\hline $80: 20$ & $7.00^{a}$ & $15.83^{\mathrm{a}}$ & $8.20^{a}$ & $2.62^{\mathrm{a}}$ & $2.30^{a}$ & $6.50^{b}$ & $22.50^{\mathrm{a}}$ \\
\hline $75: 25$ & $7.10^{\mathrm{a}}$ & $15.94^{\mathrm{a}}$ & $8.35^{\mathrm{a}}$ & $2.87^{\mathrm{a}}$ & $2.50^{\mathrm{a}}$ & $6.40^{b}$ & $23.50^{\mathrm{a}}$ \\
\hline
\end{tabular}

Values are means of three replicates; sample means with the same alphabets along the columns are not significantly different at $\mathrm{p}<0.05$; CAP: Cashew Apple Powder; CF: Cassava Flour

sample supplemented with $25 \% \mathrm{CAP}$, this biscuit sample was not significantly different from the sample supplemented with $20 \%$ CAP. The control sample had the least value for protein content (5.85\%). From the results, it showed that supplementation of cassava flour with CAP in biscuit formulation had increased the protein content of the biscuits.

There were no significant differences $(p<0.05)$ in the total ash content of the biscuit samples supplemented with 15,20 and $25 \%$ of CAP while samples made from $10 \%$ CAP supplementation and the control samples were significantly different from them. The ash content found in the biscuits supplemented with CAP was higher than that reported for biscuits made from $100 \%$ cassava flour (Oyewole et al., 1996).

There were slight differences in the values obtained for fat contents in all the biscuit samples, which increased with the level of supplementation. However, the addition of CAP did not cause a significant increase in the fat content of all the biscuit samples $(\mathrm{p}<0.05)$.

Addition of CAP significantly increased the vitamin $\mathrm{C}$ content of the biscuit samples $(\mathrm{p}<0.05)$. Biscuit supplemented with $25 \%$ CAP had the highest value $(23.50 \mathrm{mg} / 100 \mathrm{~g})$ and this sample was not significantly different from the biscuit supplemented with 20\% CAP. The least value for vitamin $\mathrm{C}$ was recorded in the control sample $(1.74 \mathrm{mg} / 100 \mathrm{~g})$. This result has shown that CAP can be a source of vitamin $\mathrm{C}$ supplementation in Cassava flour biscuits.

Table 4 shows the physical characteristics of the biscuits. The size and volume were not significantly different among the samples. However, the biscuits supplemented with CAP have slight greater weights than the reference sample. The results are similar to one reported by Oyewole et al. (1996).

Data on the sensory evaluation of the biscuits are shown in Table 5. The results showed that supplementation of cassava flour biscuits with CAP up to $20 \%$ did not significantly affect the colour, texture, crispness and taste $(\mathrm{p}<0.05)$ when compared with the control sample (biscuits made from $100 \%$ cassava flour). However, biscuit with $25 \%$ CAP was significantly different from the other samples in all parameters
Table 4: Physical evaluation of biscuit made from CF supplemented with

\begin{tabular}{lcccc}
\multicolumn{2}{c}{ CAP } \\
$\begin{array}{l}\text { Biscuits } \\
\text { CF:CAP }\end{array}$ & $\begin{array}{c}\text { Weight } \\
(\mathrm{g})\end{array}$ & $\begin{array}{c}\text { Diameter } \\
(\mathrm{cm})\end{array}$ & $\begin{array}{c}\text { Height } \\
\text { (cm) }\end{array}$ & $\begin{array}{c}\text { Spread ratio } \\
\text { (diameter/height) }\end{array}$ \\
\hline $100: 0$ & $10.20^{\mathrm{b}}$ & $5.51^{\mathrm{a}}$ & $0.50^{\mathrm{a}}$ & $11.02^{\mathrm{a}}$ \\
$90: 10$ & $10.32^{\mathrm{b}}$ & $5.52^{\mathrm{a}}$ & $0.49^{\mathrm{a}}$ & $11.26^{\mathrm{a}}$ \\
$85: 15$ & $10.85^{\mathrm{a}}$ & $5.50^{\mathrm{a}}$ & $0.50^{\mathrm{a}}$ & $11.00^{\mathrm{a}}$ \\
$80: 20$ & $11.15^{\mathrm{a}}$ & $5.53^{\mathrm{a}}$ & $0.49^{\mathrm{a}}$ & $11.29^{\mathrm{a}}$ \\
$75: 25$ & $11.30^{\mathrm{a}}$ & $5.52^{\mathrm{a}}$ & $0.49^{\mathrm{a}}$ & $11.27^{\mathrm{a}}$ \\
\hline
\end{tabular}

Values are means of three replicates; sample means with the same alphabets along the columns are not significantly different at $\mathrm{p}<0.05$; CAP: Cashew Apple Powder; CF: Cassava Flour

Table 5: Mean sensory score of biscuit made from CF supplemented with CAP

\begin{tabular}{|c|c|c|c|c|c|c|}
\hline \multirow[b]{2}{*}{$\begin{array}{l}\text { Biscuits } \\
\text { CF:CAP }\end{array}$} & \multicolumn{6}{|c|}{ Mean score of attributes } \\
\hline & Colour & Texture & Crispness & Taste & Aroma & $\begin{array}{c}\text { Overall } \\
\text { acceptability }\end{array}$ \\
\hline $100: 0$ & $5.6^{\mathrm{a}}$ & $6.2^{\mathrm{a}}$ & $5.8^{a}$ & $6.4^{a}$ & $5.3^{b}$ & $5.8^{b}$ \\
\hline $90: 10$ & $5.5^{\mathrm{a}}$ & $6.4^{\mathrm{a}}$ & $5.7^{\mathrm{a}}$ & $6.4^{\mathrm{a}}$ & $6.4^{\mathrm{a}}$ & $6.6^{\mathrm{a}}$ \\
\hline $85: 15$ & $5.6^{\mathrm{a}}$ & $6.3^{\mathrm{a}}$ & $5.6^{\mathrm{a}}$ & $6.5^{\mathrm{a}}$ & $6.6^{\mathrm{a}}$ & $6.8^{\mathrm{a}}$ \\
\hline $80: 20$ & $5.7^{\mathrm{a}}$ & $6.2^{\mathrm{a}}$ & $5.5^{\mathrm{a}}$ & $6.9^{\mathrm{a}}$ & $6.8^{\mathrm{a}}$ & $7.0^{\mathrm{a}}$ \\
\hline $75: 25$ & $4.8^{\mathrm{b}}$ & $5.3^{b}$ & $5.0^{b}$ & $5.4^{\mathrm{b}}$ & $5.5^{b}$ & $5.4^{\mathrm{b}}$ \\
\hline
\end{tabular}

evaluated. The control sample was significantly different from biscuits made with CAP supplementation in aroma and this could be due to the pleasant flavour of CAP. The overall acceptability results showed that biscuits supplemented with 10,15 and $20 \%$ were not significantly different and these were the samples preferred by the assessors.

\section{CONCLUSION}

This study showed that the quality of cassava flour biscuits could be improved with supplementation of cashew apple powder, in term of protein, fibre, ash and vitamin C. Physical evaluation of the biscuits showed that there were no significant differences in all the samples and the control.

The whole cassava flour biscuits were no significantly different from the cashew apple powder supplemented biscuits up to $20 \%$ in all sensory attributes tested except aroma, which may be due to the pleasant flavour of cashew apple powder. The combination of cassava flour and cashew apple powder, which are local 
raw materials for biscuits making will reduce the cost of production when compared with the use of wheat flour. Therefore, cashew apple powder addition in cassava flour biscuits formulation seems to be better suited for biscuit process and enrichment.

The use of CAP in cassava flour biscuits supplementation will provide additional utilization for over $90 \%$ of cashew apples that are wasted annually in Nigeria and also increase the income of the cashew farmers.

\section{REFERENCES}

Aderiye, B.I.I., M.A. Akparuna and P. Akubor, 1991. Effect of fermentation variables on the quality of cashew wine. J. Agric. Sc. Technol., 1 (1): 66-69.

Akinwale, T.O., 1999. Fermentation and post fermentation changes in Cashew Wine. J. Food Technol. Afr., 4 (3): 100-102.

Akinwale, T.O., 2000. Cashew apple juice: Its uses in fortifying the nutritional quality of some tropical fruits. European Food Res. Tech., 21 1: 205-207.

Almazan, A.M., 1987. Roots and Tubers for Bread Production. Paper presented at the workshop on the use of non-wheat flour for Bread and Biscuits Production. Obafemi Awolowo University, Ile-Ife, Nigeria.

Balagopalan, C., 2002. Cassava Utilization in Food and Feed Industry. In: Hillocks, R.J., J.M. Thresh and A.C. Belloti (Eds.). Biology, production and utilization, CAB International, Cassava, pp: 301-318.

Camire, M.E., M.P. Douggherty and J.L. Briggs, 2007. Functionality of fruit powders in extruded corn breakfast cereals. Food Chem., 101 (2): 765-770.

Cavalcante, A.A.M., G. Rubensam, B. Erdtmann, M. Brendel and J.A.P. Henriques, 2005. Cashew (Anacardium occidentale L.) apple juice lowers mutagenicity of aflatxin $\mathrm{Bl}$ in S. typhimurium $\mathrm{TA} 102$. Gen. Mol. Biol., 28: 328-333.

Cormier, R., 2008. Clarification of cashew apple juice and commercial applications. Oxfarm Quebec, Benin, West Africa.

Eggleston, G., P. Omoaka and A.U. Arowoshegbe, 1993. Flour, starch and composite Bread making quality of various cassava clones. J. Sci. Food Agric., 62: 49-59.

Eneche, E.H., 1999. Biscuit-making potential of millet/pea flour blends. Plant Foods for Human Nutr., 54: 21-27.

FAO, 2004. FAO Statistics, http://faostat.fao.org/ faostat/ collections?version $=$ ext\&hasbulk $=0 \&$ subset $=$ agric ulture.
FAO, 2008. Food Agriculture Organization of United Nations. Crop Production Statistics database division. http://faostart.fao.org/site/567/Destop Default.Aspx?page10= 567 \# ancor.

Gomez, A.K. and A.A. Gomez, 1985. Statistical Procedure for Agricultural Research. Wiley, New York.

Gomez, M.V., L.E. Zapata and C. Pardo, 1983. Cyanide elimination, Chemical composition and evaluation in bread making of oven dried cassava peeled root chips or slices. J. Food Tech., 19: 493-498.

Kim, J.C. and D. de Ruiter, 1968. Bread from non-wheat flours. Food Tech., 22 (7): 867-878.

Kirk, R.S. and R. Sawyer, 1991. Pearson's Composition and Analysis of Foods. 8-9th Edn. Revised edition of: Pearson's Chemical Analysis of Foods. TX545.K53 (1991). 664-07-dc20. ISBN: 0-470-21693-X. Longman Singapore Publishers (Pte) Ltd. Singapore pp: 283-329.

Kulkarni, S.D., 1997. Roasted soybean in cookies: Influence on product quality. J. Food Sci. Tech., 34: 503-505.

Larrea, M.A., Y.K. Chang and F. Martinez-Bustosc, 2005. Some functional properties of extruded orange pulp and its effect on the quality of cookies. LWT-Food Sci. Tech., 38: 213-220.

Melo-Cavalcante, A.A., G. Rubensam, J.N. Picada, E.G. Silva, F.J.C. Moreira and J.A.P. Henriques, 2003. Mutagenic evaluation, antioxident potential and antimutagenic activity against hydrogen peroxide of cashew (Anacardium occidentale) apple juice and cajuina. Environ. Mol. Mutagen., 41: 360-369.

Morton, J., 1987. Cashew Apple. In: Miami, F.L. (Ed.). Fruits of Warm Climates, pp: 239-240.

Morton, S., 1988. Bread without wheat. J. New Scientist.

Oduwole, O.O., T.O. Akinwale and O. Olubamiwa, 2001. Economic evaluation of a locally fabricated extraction machine for a cottage cashew juice factory. J. Food Tech. Afr., 6(1): 18-20.

Ogunmoyela, A.O., 1983. Prospects of cashew apple processing and utilization in Nigeria. Process. Biochem., 23: 6-7.

Ohler, J.G., 1988. Cashew Communication 71. Department of Agricultural Research, Koninklijk Institnut voor de Tropen, Amsterdam, pp: 260. ISBN: 9068320742.

Omoaka, P. and M. Bokanga, 1994. Cassava in the production of bread and bakery products. Proc. 5th Symp. ISTRC. AB., pp: 340-342.

Oyewole, O.B., L.O. Sanni and M.A. Ogunjobi, 1996. Production of Biscuits using cassava flour. Nig. Food J., 14: 24-29. 
Steel, R.G.D. and J.H. Torrie, 1980. Principles of Statistics, McGraw-Hill, New York.

Shittu, T.A., A. Dixon, S.O. Awonorin, L.O. Sanni and B. Maziya-Dixon, 2008. Bread from composite cassava-wheat flour. II: Effect of cassava genotype and nitrogen fertilizer on bread quality. Food Res. Int., 41: 569-578. DOI: 10.1016/j.foodres.2008.03.008

Shuklajasha Mohanty, Pratima Ray, M.R. Swain and R.C. Ray, 2005. Fermentation of cashew (Anacardium occidentale) Apple into wine. J. Food Processing and Preservation, 30 (3): 314-322.
Smith, W.H., 1972. Wire-cut Cookies. In: Smith, W.H. (Ed.). Biscuits, crackers and cookies: Technology, Production and Management. Applied Sci. Publishers, London, pp: 737.

Wade, P., 1988. Biscuits, Cookies and Crackers: The Principle of Craft, 1: 1-4.

Winterhalter, P., 1991. Fruits IV. In: Mearse, H. (Ed.). Volatile Compounds in Food and Beverages, Marcel Dekker, New York, pp: 389-409. ISBN: 97808 24783907. 